\title{
Paroxysmal Hypertension
}

National Cancer Institute

\section{Source}

National Cancer Institute. Paroxysmal Hypertension. NCI Thesaurus. Code C9236.

Hypertension that presents intermittently. 